\title{
Activation of a Cryptic Splice Site of GFAP in a Patient With Adult-Onset Alexander Disease
}

Eiichiro Amano, MD, Tomokatsu Yoshida, MD, PhD, Ikuko Mizuta, MD, PhD, Jun Oyama, MD, PhD,

Shingo Sakashita, MD, PhD, Syunsuke Ueyama, MD, Akira Machida, MD, PhD, and Takanori Yokota, MD, PhD

Neurol Genet 2021;7:e626. doi:10.1212/NXG.0000000000000626

\author{
Correspondence \\ Dr. Amano \\ eiichiroamano1122@hotmail.co.jp
}

\section{Abstract}

\section{Background and Objective}

Alexander disease (ALXDRD) is an autosomal dominant neurologic disorder caused by mutations in the glial fibrillary acidic protein (GFAP) gene and is pathologically defined by Rosenthal fiber accumulation. Most mutations are exonic missense mutations, and splice site mutations are rare. We report a very-late-onset autopsied case of adult-onset ALXDRD with a novel splice site mutation.

\section{Methods}

Genetic testing of GFAP was performed by Sanger sequencing. Using autopsied brain tissues, GFAP transcript analysis was performed.

\section{Results}

The patient presented mild upper motor neuron symptoms in contrast to the severe atrophy of spinal cord and medulla oblongata. The patient had c.619-1G $>$ A mutation, which is located in the canonical splice acceptor site of intron 3. The brain RNA analysis identified the r.619 621del (p.Glu207del) mutation, which is explained by the activation of the cryptic splice acceptor site in the second and third nucleotides from the $5^{\prime}$ end of the exon 4.

\section{Discussion}

GFAP gene expression analysis is necessary to clarify the effects of intronic mutations on splicing, even if they are in canonical splice sites. This case showed a much milder phenotype than those in previous cases with missense mutations at Glu207, thereby expanding the clinical spectrum of ALXDRD with Glu207 mutation.

From the Department of Neurology and Neurological Science, Graduate School of Medical and Dental Sciences, Tokyo Medical and Dental University (E.A., T. Yokota); Department of Neurology, Tsuchiura Kyodo General Hospital (E.A., A.M.), Ibaraki; Department of Neurology, Graduate School of Medical Science, Kyoto Prefectural University of Medicine (T. Yoshida, I.M.); Department of Radiology, Tokyo Medical and Dental University (J.O.); Department of Pathology, Tsuchiura Kyodo General Hospital (S.S.), Ibaraki; Division of Pathology, Exploratory Oncology Research and Clinical Trial Center, National Cancer Center (S.S.), Chiba; and Department of Gastroenterology, Tsuchiura Kyodo General Hospital (S.U.), Ibaraki, Japan.

Go to Neurology.org/NG for full disclosures. Funding information is provided at the end of the article 


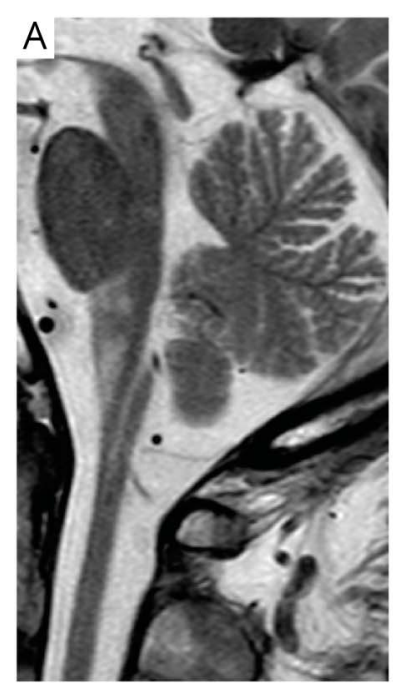

$\mathrm{D}$

Sequencing analysis
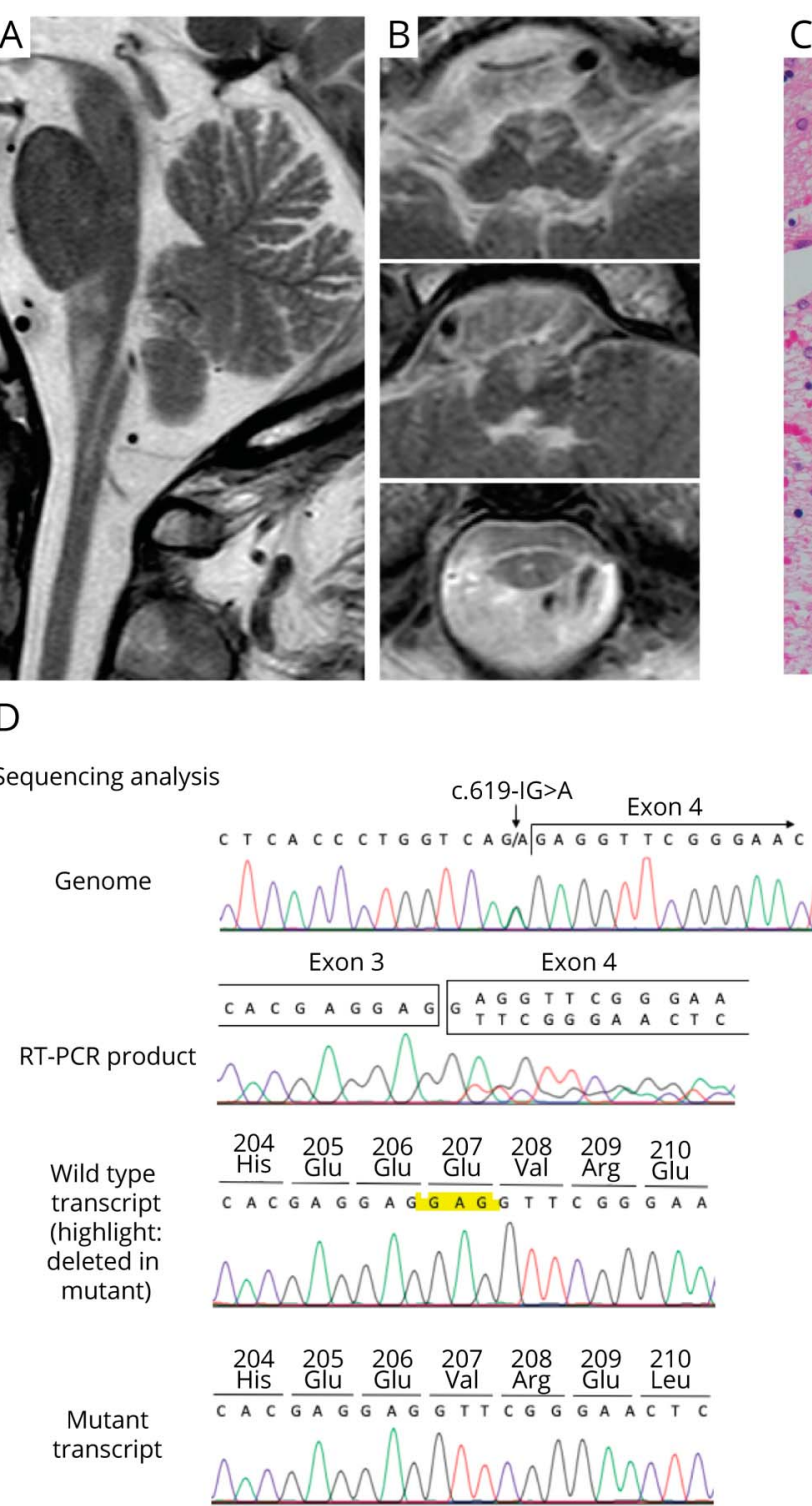

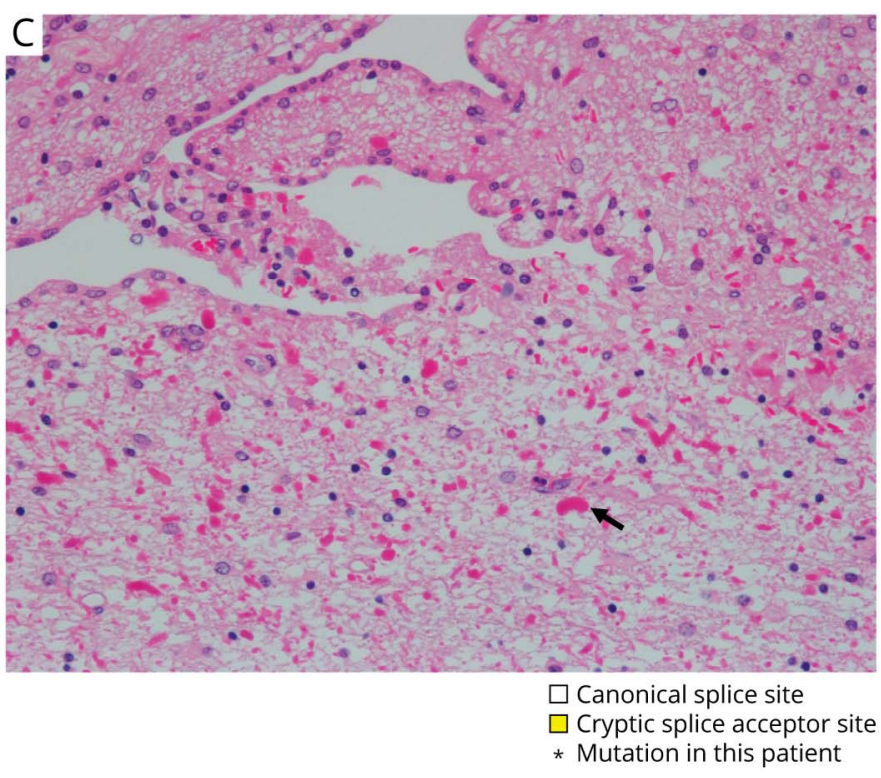

Activation of cryptic splice acceptor site in exon 4
Wild type $\underbrace{\text { Exon } 3}_{\text {CACGAGGAG }} \ldots \ldots \ldots$ ag

Mutant

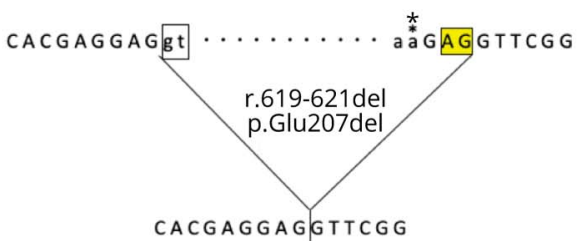

(A) Sagittal section on T2-weighted MRI revealed abnormal high intensities in the ventral medulla oblongata. (B) Axial sections on T2-weighted MRI revealed ventral-dominant abnormal intensities and atrophy of the medulla oblongata and upper cervical spine. (C) Rosenthal fibers were widely identified via hematoxylin-eosin staining (magnified at 200x). Periventricular lesion underlying the choroid plexus of the lateral ventricle. The arrow indicates one of the Rosenthal fibers. (D) Sequencing analysis of genomic DNA identified heterozygous c.619-1G>A mutation (left panel). Cloning and sequencing of RT-PCR product revealed GAG (r.619_621 del, p. Glu207del) deletion. These findings suggested that c.619-1G>A led to activation of a cryptic splice acceptor site in the second and third nucleotides from the $5^{\prime}$ end of exon 4, generating p. Glu207del (right panel). RT-PCR = reverse transcription-PCR.

Alexander disease (ALXDRD) is an autosomal dominant neurologic disorder caused by mutations in the glial fibrillary acidic protein (GFAP) gene and is pathologically defined by Rosenthal fiber accumulation. ${ }^{1}$ The clinical course of adultonset ALXDRD is heterogeneous and sometimes mild or even asymptomatic despite the remarkable atrophy of the brainstem and spinal cord on MRI. ${ }^{2}$ Most causative mutations are exonic missense ones, and very few splice site mutations have been reported. ${ }^{3}$ When elucidating the effect of mutations in the splice site, expression analysis using RNA extracted from CNS tissues is required because the expression of GFAP is specific to astrocytes.
Here, we describe an autopsied case of adult-onset ALXDRD with a novel splice site mutation presenting with elderlyonset mild upper motor neuron symptoms in contrast to the severe atrophy of the spinal cord and medulla oblongata. This mutation is located in the canonical splice acceptor site, and brain RNA analysis identified a three-base deletion, which is explained by the activation of the cryptic splice acceptor site.

\section{Data Availability}

Anonymized data not published within this article will be made available to qualified investigators. 


\section{Ethics Approval} Medicine approved the genetic testing.

\section{Consent to Participate}

Before the patient died, written informed consent was obtained from the patient for the genetic testing. The written informed consent for the autopsy study was obtained from the family of the patient based on the patient's own will before death.

\section{Consent for Publication}

Before the patient died, written informed consent was obtained from the patient for the publication of the result of genetic testing in anonymized fashion. The written informed consent of publication of the autopsy study in anonymized fashion was also obtained from the family of the patient based on the patient's own will before death.

\section{Case Report}

A 76-year-old man with neither medical history nor family history of neurologic diseases presented with progressive diplopia and ptosis in his left eye. Neurologic examination revealed complete ophthalmoplegia, loss of light reflex, and ptosis in the left eye, indicating palsies of cranial nerves III, IV, and VI. Mild spastic gait with bilateral positive Babinski reflex and increased deep tendon reflex in all limbs was observed. He could walk without assistance, and no other neurologic abnormalities were observed.

Brain MRI revealed orbital schwannoma extending from the left orbital apex and superior orbital fissure toward the orbital cavity. In addition, systemic screening revealed gastric adenocarcinoma with multiple metastases in para-aortic lymph nodes. Unexpectedly, brain and spinal MRI revealed bilateral abnormal high intensities in the ventral medulla oblongata, a mild periventricular hyperintensity lesion, and marked spinal cord atrophy (Figure, A and B). These findings are characteristic of adult-onset ALXDRD, ${ }^{1}$ and Sanger sequencing analysis of GFAP disclosed a novel heterozygous c.619-1G>A mutation.

The patient died of multiple metastases of adenocarcinoma and pneumonia 6 months after diagnosis. Autopsy revealed marked atrophy of the medulla and spinal cord. Fibrotic astrocyte degeneration, Rosenthal fiber deposition, and myelin loss were widespread in the medulla, spinal cord, and periventricular locations underlying the lateral ventricles and fourth ventricle (Figure C), which was pathologically compatible with ALXDRD. ${ }^{4}$ Neurons in the anterior horn and cerebral cortex were relatively reserved. The orbital lesion was schwannoma, which was confirmed by the typical palisading with positive S-100 staining and negative GFAP staining immunohistochemistry and considered not to be related to ALXDRD.

Because c.619-1G $>\mathrm{A}$ is located in the canonical splice acceptor site of intron 3 , we initially expected that this mutation would result in exon 4 skipping. Indeed, a previous study of a patient
The Ethics Committee of Kyoto Prefectural University of

with a heterozygous c.619-3C>G mutation showed exon 4 skipping in approximately $10 \%$ of the transcripts. ${ }^{3}$ However, analysis of RNA from the autopsied brain tissue of the present patient showed deletion of GAG (r.619_621del) (Figure D). The reverse transcription-PCR product was cloned, and 54 individual clones in total were sequenced. The number of wildtype and mutant clones was 34 and 20, respectively. These findings suggested that c.619-1G>A caused activation of the cryptic splice acceptor site in the second and third nucleotides from the $5^{\prime}$ end of exon 4 (Figure D), in approximately $37 \%$ $(20 / 54)$ of the transcripts. r.619_621del results in loss of Glu207, which is located in the $\alpha$-helical segment 1B. Loss of Glu207 is believed to be pathogenic because the missense mutations at Glu207, p.Glu207Gln, ${ }^{5}$ p.Glu207Lys, ${ }^{6}$ and p.Glu207 $\mathrm{Val}^{7}$ have been previously reported in patients with ALXDRD. Patients with p.Glu207Gln and p.Glu207Lys were juvenile onset, whereas the patient with p.Glu207Val presented symptoms including dysphagia and dysarthria at age 52 years, earlier onset than the present patient with p.Glu207del. These suggest that the broad clinical spectrum of mutations at Glu207 and p.Glu207del may be related to milder phenotype than missense mutations at Glu207. As the number of cases with Glu207 mutation is limited, further study is necessary to address the phenotypic heterogeneity of the mutations at Glu207.

In conclusion, we identified a novel ALXDRD-causing GFAP mutation in the splice acceptor site of intron 3, leading to activation of a cryptic splice site in exon 4 . This splicing error resulted in very-late-onset pyramidal signs, which were milder than expected from the severe atrophy of spinal cord and medulla caused by astrocyte degeneration. GFAP gene expression analysis using CNS tissues was necessary to clarify the effect of intronic mutations on splicing.

\section{Study Funding}

No targeted funding reported.

\section{Disclosure}

No relevant competing interest was declared by the authors. Go to Neurology.org/NG for full disclosures.

\section{Publication History}

Received by Neurology: Genetics May 31, 2021. Accepted in final form August 13, 2021.

\section{Appendix Authors}

\begin{tabular}{|c|c|c|}
\hline Name & Location & Contribution \\
\hline $\begin{array}{l}\text { Eiichiro } \\
\text { Amano, MD }\end{array}$ & $\begin{array}{l}\text { Department of Neurology } \\
\text { and Neurological Science, } \\
\text { Graduate School of Medical } \\
\text { and Dental Sciences, Tokyo } \\
\text { Medical and Dental } \\
\text { University, Tokyo, Japan; } \\
\text { Department of Neurology, } \\
\text { Tsuchiura Kyodo General } \\
\text { Hospital, Ibaraki, Japan }\end{array}$ & $\begin{array}{l}\text { Drafting/revision of the } \\
\text { manuscript for content, } \\
\text { including medical writing for } \\
\text { content; major role in the } \\
\text { acquisition of data; study } \\
\text { concept or design; and } \\
\text { analysis or interpretation of } \\
\text { data }\end{array}$ \\
\hline
\end{tabular}


Appendix (continued)

\begin{tabular}{|c|c|c|}
\hline Name & Location & Contribution \\
\hline $\begin{array}{l}\text { Tomokatsu } \\
\text { Yoshida, } \\
\text { MD, PhD }\end{array}$ & $\begin{array}{l}\text { Department of Neurology, } \\
\text { Graduate School of Medical } \\
\text { Science, Kyoto Prefectural } \\
\text { University of Medicine, Kyoto, } \\
\text { Japan }\end{array}$ & $\begin{array}{l}\text { Drafting/revision of the } \\
\text { manuscript for content, } \\
\text { including medical writing for } \\
\text { content; study concept or } \\
\text { design; and analysis or } \\
\text { interpretation of data }\end{array}$ \\
\hline $\begin{array}{l}\text { Ikuko } \\
\text { Mizuta, MD, } \\
\text { PhD }\end{array}$ & $\begin{array}{l}\text { Department of Neurology, } \\
\text { Graduate School of Medical } \\
\text { Science, Kyoto Prefectural } \\
\text { University of Medicine, Kyoto, } \\
\text { Japan }\end{array}$ & $\begin{array}{l}\text { Drafting/revision of the } \\
\text { manuscript for content, } \\
\text { including medical writing for } \\
\text { content; study concept or } \\
\text { design; and analysis or } \\
\text { interpretation of data }\end{array}$ \\
\hline $\begin{array}{l}\text { Jun Oyama, } \\
\text { MD, PhD }\end{array}$ & $\begin{array}{l}\text { Department of Radiology, } \\
\text { Tokyo Medical and Dental } \\
\text { University, Tokyo, Japan }\end{array}$ & $\begin{array}{l}\text { Analysis or interpretation of } \\
\text { data }\end{array}$ \\
\hline $\begin{array}{l}\text { Shingo } \\
\text { Sakashita, } \\
\text { MD, PhD }\end{array}$ & $\begin{array}{l}\text { Department of Pathology, } \\
\text { Tsuchiura Kyodo General } \\
\text { Hospital, Ibaraki, Japan; } \\
\text { Division of Pathology, } \\
\text { Exploratory Oncology } \\
\text { Research and Clinical Trial } \\
\text { Center, National Cancer } \\
\text { Center, Chiba, Japan }\end{array}$ & $\begin{array}{l}\text { Analysis or interpretation of } \\
\text { data }\end{array}$ \\
\hline $\begin{array}{l}\text { Syunsuke } \\
\text { Ueyama, } \\
\text { MD }\end{array}$ & $\begin{array}{l}\text { Department of } \\
\text { Gastroenterology, Tsuchiura } \\
\text { Kyodo General Hospital, } \\
\text { Ibaraki, Japan }\end{array}$ & $\begin{array}{l}\text { Analysis or interpretation of } \\
\text { data }\end{array}$ \\
\hline
\end{tabular}

Appendix (continued)

\begin{tabular}{lll}
\hline Name & Location & Contribution \\
\hline $\begin{array}{l}\text { Akira } \\
\text { Machida, } \\
\text { MD, PhD }\end{array}$ & $\begin{array}{l}\text { Department of Neurology, } \\
\text { Tsuchiura Kyodo } \\
\text { General Hospital, } \\
\text { lbaraki, Japan }\end{array}$ & $\begin{array}{l}\text { Analysis or interpretation of } \\
\text { data }\end{array}$ \\
\hline $\begin{array}{l}\text { Takanori } \\
\text { Yokota, } \\
\text { MD, PhD }\end{array}$ & $\begin{array}{l}\text { Department of Neurology } \\
\text { and Neurological Science, } \\
\text { Graduate School of Medical } \\
\text { and Dental Sciences, Tokyo } \\
\text { Medical and Dental }\end{array}$ & $\begin{array}{l}\text { Study concept or design and } \\
\text { data }\end{array}$ \\
& $\begin{array}{l}\text { University, Tokyo, Japan } \\
\end{array}$ & \\
&
\end{tabular}

\section{References}

1. Yoshida T. Clinical characteristics of Alexander disease. Neurodegener Dis Manag. 2020;10(5):325-333.

2. Sugiyama A, Sawai $S$, Ito $S$, et al. Incidental diagnosis of an asymptomatic adult-onset Alexander disease by brain magnetic resonance imaging for preoperative evaluation. J Neurol Sci. 2015;354(1-2):131-132.

3. Flint D, Li R, Webster LS, et al. Splice site, frameshift, and chimeric GFAP mutations in Alexander disease. Hum Mutat. 2012;33(7):1141-1148.

4. Sosunov A, Olabarria M, Goldman JE. Alexander disease: an astrocytopathy that produces a leukodystrophy. Brain Pathol. 2018;28(3):388-398.

5. van der Knaap MS, Salomons GS, Li R, et al. Unusual variants of Alexander's disease. Ann Neurol. 2005;57(3):327-338.

6. Rong L, Johnson AB, Salomons G, et al. Glial fibrillary acidic protein mutations in infantile, juvenile, and adult forms of Alexander disease. Ann Neurol. 2005;57(3): 310-326.

7. Gass JM, Cheema A, Jackson J, Blackburn PR, Van Gerpen J, Atwal PS. Novel GFAP variant in adult-onset Alexander disease with progressive ataxia and palatal tremor. Neurologist. 2017;22(6):247-248 


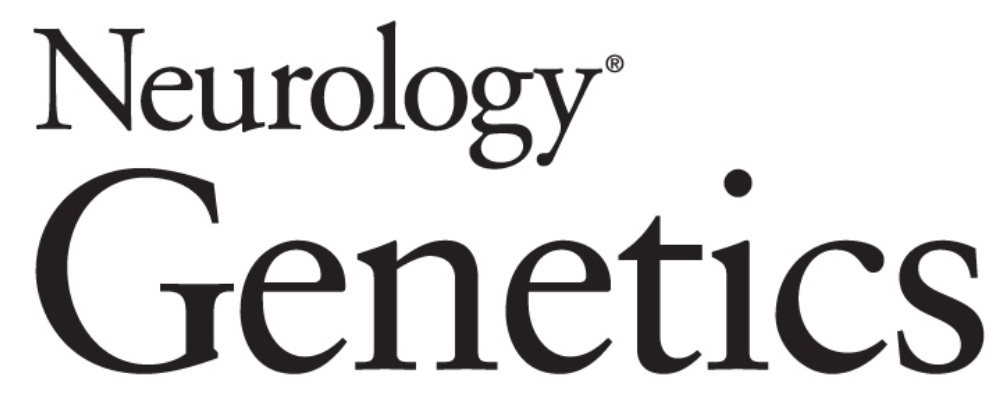

\section{Activation of a Cryptic Splice Site of GFAP in a Patient With Adult-Onset Alexander Disease}

Eiichiro Amano, Tomokatsu Yoshida, Ikuko Mizuta, et al. Neurol Genet 2021;7;

DOI 10.1212/NXG.0000000000000626

\section{This information is current as of October 1, 2021}

\section{Updated Information \&} Services

\section{References}

Subspecialty Collections

Permissions \& Licensing

Reprints including high resolution figures, can be found at: http://ng.neurology.org/content/7/6/e626.full.html

This article cites 7 articles, 0 of which you can access for free at: http://ng.neurology.org/content/7/6/e626.full.html\#\#ref-list-1

This article, along with others on similar topics, appears in the following collection(s):

All Clinical Neurology

http://ng.neurology.org//cgi/collection/all_clinical_neurology All Genetics

http://ng.neurology.org//cgi/collection/all_genetics

Gene expression studies

http://ng.neurology.org//cgi/collection/gene_expression_studies

MRI

http://ng.neurology.org//cgi/collection/mri

Information about reproducing this article in parts (figures,tables) or in its entirety can be found online at:

http://ng.neurology.org/misc/about.xhtml\#permissions

Information about ordering reprints can be found online: http://ng.neurology.org/misc/addir.xhtml\#reprintsus

Neurol Genet is an official journal of the American Academy of Neurology. Published since April 2015, it is an open-access, online-only, continuous publication journal. Copyright Copyright $(2021$ The Author(s). Published by Wolters Kluwer Health, Inc. on behalf of the American Academy of Neurology.. All rights reserved. Online ISSN: 2376-7839.

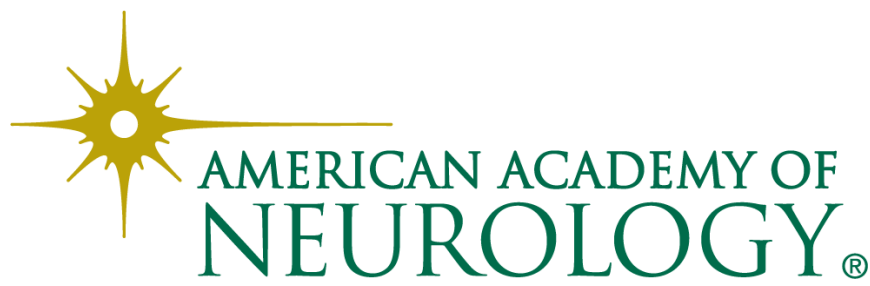

